\title{
Arranjos domésticos brasileiros testemunhados por periódicos da década de 1920
}

\section{Brazilian home arrangements witnessed by magazines of the 1920s}

\author{
(iD) Rosane Costa Badan
Universidade Federal de Goiás (UFG), Goiânia, Goiás, Brasil \\ rosane_badan@ufg.br
}

\section{Resumo}

O artigo traz contibuições originais a um projeto de pesquisa que trata da história dos ambientes interiores de Goiânia, cujos resultados apontam em direção à influência exercida pelo eixo Rio-São Paulo na orientação das escolhas materiais e do modo de viver das pessoas em relação à casa e à arrumação dos arranjos domésticos. A objetivo da pesquisa é preencher a lacuna da escassez de dados sistematizados sobre a história dos interiores brasileiros e colaborar na compreensão do lar brasileiro - e, por consequência, dos ambientes domésticos de Goiânia. As informações trazidas pelas revistas especializadas espelham de forma quase precisa os fatos, as preferências, os modos de vida do Brasil da década de 1920, todavia, se os dados não estiverem sistematicamente organizados, a fragmentação dos eventos não permite uma visão holística desse enredo. No Brasil, a tendência moderna foi um direcionamento bem recebido e a arte decorativa se tornou necessária nas opções domésticas da casa. No mobiliário moderno, em particular, sem desprezar 
o efeito decorativo, determinava-se que tudo devia se revestir de utilidade e conforto. Considerando os recursos de comodidade e higiene, era fundamental levar em conta o destino que cada peça teria na composição do lar, fazendo-se necessário dominar a arte da mobiliação. Nos anos 1920, acreditava-se erroneamente que o conceito modern style resultava da importação em bloco de elementos decorativos estrangeiros. Na verdade, o modern style, adaptado e modificado pela produção nacional, deu provas do bom gosto e, por consequência, teve a aceitação do público. Os hábitos modernos, além de remodelar, reinventaram ambientes, mas as novidades advindas da Europa reforçavam a predisposição de confiar mais naquilo que era estrangeiro. Costumava-se pensar que tudo que se fazia no exterior era melhor e mais bem feito daquilo que se produzia no Brasil. Na arrumação da casa, os estilos do passado não eram repudiados pelo modernismo, desde que a Arte fosse considerada, adequando-os às exigências racionais e práticas da vida presente naqueles dias, ou seja, sem decorações supérfluas. Dizendo em outras palavras, o móvel moderno ou de inspiração antiga, além do seu lado racional, deveria ter os elementos estilísticos individuais que formavam a sua fisionomia, ao mesmo tempo que complementassem a casa. Por isso, a propensão ao ecletismo.

Palavras-chaves: Arranjos domésticos; Arte decorativa; Mobiliário; Moderno; Ecletismo.

\section{Abstract}

This article brings original contributions to a research project that discusses the history of interior environments in Goiânia. The results point towards the influence of Rio-São Paulo axis in choosing materials and way of life of people in relation to the house and the domestic arrangements. The main research objective is to fill the gap in the scarcity of systematized data about the history of interior design in Brazil and understanding it and, consequently, the domestic environments of Goiania. Information from specialized 
magazines reflects facts, choices, ways of life in the 1920s Brazil, almost accurately. However, if these data are not systematically organized, the fragmentation of events does not allow a holistic view of this context. In Brazil, modern trend was a well-received direction and decorative art became necessary in the home's domestic choices. In modern furniture, in particular, without neglecting the decorative effect, it determined that everything should have utility and comfort. Taking into account convenience and hygiene resources, it was essential considering the destination that each piece would have in the home arrangement, making it necessary to master the furniture art. In the 1920s, it was mistakenly believed that the modern style concept resulted from the importation of foreign decorative elements "en bloc". In fact, modern style, adapted and modified by the national production, showed good taste and, consequently, it was accepted by the people. Modern habits remodeled and reinvented environments, but novelties coming from Europe reinforced the predisposition to trust more that which was foreign. It was normal thinking that everything which was done abroad was better than what produced in Brazil. In house's arrangements, styles of past were not repudiated by modernism, but it was necessary considering Art, adapting them to the rational and practical demands of present life, that is, without superfluous decorations. In other words, modern furniture or in antique inspiration, in addition to its rational side, should had individual stylistic elements able to form its physiognomy and complementing the house. That is the reason for eclecticism propensity.

Keywords: Home arrangements; Decorative art; Furniture; Modern; Eclecticism. 


\section{Um novo ismo}

O presente texto subsidia o entendimento do projeto de pesquisa "Evolução histórica dos ambientes interiores e do mobiliário de Goiânia: análise de casas de elite e de sobrados residenciais construídos entre 1933 e 1975", iniciado em 2013, na Universidade Federal de Goiás. As pesquisas sobre Goiânia indicaram o alto grau de influência que o eixo Rio-São Paulo exerceu na orientação das opções materiais e do modo de viver das pessoas, em praticamente todos os estados brasileiros. Englobando os aspectos da vida feminina na sua completude, falava-se da necessidade de "seguir tendências" e de "estar na moda", o que incluía a casa e os arranjos domésticos.

Por essa razão, o recorte temporal precisou se ampliar e abarcar os anos que antecederam aquela pesquisa, a saber, a década de 1920. Seguindo metodologia correlata, a coleta de dados continuou sendo substancialmente estruturada em fontes primárias publicadas na data de interesse, sobretudo, em periódicos especializados na temática do lar. Optou-se por evitar a historiografia e qualquer outra interpretação secundária que não fosse aquela fornecida pelo primeiro interlocutor do assunto, exceto em situações particulares.

A partir de orientações dadas na época por conhecedores de ambientes domésticos ${ }^{1}$, o assunto tratado é relatado em quatro partes distintas. A primeira abrange o texto corrente e introduz o modernismo no contexto do lar. Já a segunda discorre a respeito da importância estética da arte decorativa e da inserção do moderno na vida privada brasileira, considerando precipuamente as inovações que o lar adquirira. Localiza ainda alguns produtores e fornecedores de artefatos domésticos em âmbito nacional. A terceira parte apresenta a maneira como uma casa era mobiliada e decorada entre os anos 1920 e 1929. Para isso, identificou o lugar onde os móveis se acomodavam em três compartimentos distintos da habitação: o living-room, a sala de jantar e a cozinha. A última parte indica sinteticamente os elementos de transfomação que mais se evidenciaram naquela década.

\footnotetext{
1 Braz Jordão, Marianna Dorne e Joanna Brandt foram alguns especialistas que escreveram para as revistas cariocas "A Casa" e "Vida Doméstica". A título de exemplo, para o desenvolvimento da presente pesquisa, somente na revista "A Casa" foram analisadas 68 edições, o que corresponde a sete anos da história cotidiana do lar brasileiro. Da revista "Vida Doméstica" foram visitadas outras 170 edições (nove anos de história), e assim ocorreu com cada material indicado nas referências bibliográficas.
} 


\section{Arranjos domésticos brasileiros testemunhados por periódicos da década de 1920}

A fim de corroborar com pesquisas futuras, ao invés de apresentar apenas sucintamente as referências bibliográficas em conformidade com a ABNT, optamos por registrar nas notas de rodapé e ao longo do texto, o nome do periódico onde cada informação foi compilada, juntamente com a edição e a data inseridas no material de origem. Não é o propósito abastecer esse texto com críticas contemporâneas, juízos de valor nem confrontar os ditames e os caminhos seguidos outrora; outrossim, agrupar ordenadamente as informações para colocar em evidência os fatos. O objetivo é, portanto, preencher parcialmente a lacuna da escassez de dados sistematizados sobre os arranjos domésticos brasileiros na década citada e colaborar na compreensão do lar brasileiro - e, por consequência, do lar goianiense. Entretanto, não é possível estudar a cotidianidade e as escolhas feitas pelas pessoas daquele período sem mencionar alguns aspectos responsáveis pelo desencadeamento das transformações da sociedade que, por sua vez, respingaram no seio das famílias da nação.

Das transformações ocorridas, os primeiros anos do século $X X$ assistiram ao espetáculo da decadência do cosmopolitismo, onde naufragou o entusiasmo pela ciência. Desapareceram as figuras centrais daquela escola, restando os fracos, os indolentes e os pusilânimes que a ela se apegaram com o pretexto de encobrir sua degenerescência moral. Nesse contexto, submergiu a vida dos salões e em meio ao luxo e à elegância, imperou a beleza intelectual. Corriam em declive, os movimentos literário e artístico do século XIX, enquanto o cosmopolita passava a ser sinônimo de alma sem patriotismo, sem obrigações, sem deveres; em outras palavras, uma alma aberta platonicamente às ideias novas, não distinguindo o erro da verdade, o brio da vergonha. No entanto, conservou a aparência de deslocação e trânsito constantes entre países, guardando a feição de simpatia para com todos, mas desvirtuou-se. Sua vida era de exterioridade, movendo-se nos salões dos bailes, às mesas dos jantares, entre as melodias dos concertos. A esperança passou então para as mãos da mulher e do feminismo incipiente, cuja tarefa era espalhar, incentivar, propagar e disseminar a cultura científica nos seio da sociedade, acabando com os preconceitos de raças e a estreiteza de pensamento regional. Reconhecia-se que o cosmopolitismo político era uma aberração social, mas acreditava-se na renovação do cosmopolitismo científico². 
Para mais, o homem patriota retornara da grande guerra cansado, nervoso, descontente e agressivo. Julgou finalmente ter a oportunidade de repousar em casa para refazer suas energias, no entanto, precisou voltar às ocupações laborativas com maior ador que dantes, haja vista que a vida, desfalcada em virtude do conflito, não permitia o sossego esperado. A cotidianidade parecia mais dura e penosa, o que levou o cidadão a separar, em todas as conversas, o valor militar do valor civil. O antigo combatente não tinha mais a paciência, a perseverança, a tenacidade e o bom humor de outrora, pois pairava no ar que a vitória não fora nitidamente firmada ${ }^{3}$. A respeito desse sentimento de fracasso, Mario Poppe escreveu alguns meses depois que "o mundo acaba de sair da grande guerra, tinto de sangue. Mas, a sede de sangue ainda não está saciada. As estatísticas do crime cresceram depois da guerra, como que repercutindo e dilatando até o infinito, as suas consequências." 4

Tudo somado, o desejo constante de renovação era almejado em toda parte. Talvez por isso, em meados da década de 1920, a casa moderna adquiria, a todo momento, detalhes cada vez mais práticos e a cultura revelava-se plena de imponderáveis e acertadas ideias. O modernismo caminhava a passos largos, dando ao ambiente doméstico um aspecto senhorial e austero, porém confortável ao corpo e ao espírito.

A arte ressurgia nos lares com esplêndida energia. Nas casas elegantes, mostrava-se um supremo alarde de riqueza e bom gosto. As paredes tomadas por pinturas assinadas por grandes artistas eram o reflexo do que se esperava como tendência futura: a arte em todas as suas manifestações. Os tapetes, seus fiéis devotos, podiam trazer a pintura vazada em qualquer estilo, conseguindo se harmonizar nos menores detalhes. A escolha do mobiliário era também fundamental. Por fim, a pintura mural com paisagens ou histórias marinhas infundiam no ambiente um aspecto romântico e uma sensação completa de ar livre, ao passo que almofadões acurados adornavam divãs e aparadores apoiavam bibelôs ${ }^{5}$.

Considerada uma fase de absurdas frivolidades, a expectativa era que surgisse VIDA DOMÉSTICA, Rio de Janeiro, Edição 00075, abr.1924.

VIDA DOMÉSTICA, Rio de Janeiro, Edição 00077, jun.1924.

“Designação genérica de pequenos objetos decorativos, bonitos e/ou curiosos, que se coloca sobre os móveis sem finalidade útil." (MOUTINHO, 2011, p. 47). 
uma inteligência austera, sonhadora, apta a salvar a situação. Na França, os grandes designers introduziram o pensamento de que a casa devia ser amável refúgio, onde a mulher poderia mostrar-se na plenitude, sem recorrer a outras tendências menos adequadas à sensibilidade feminina.

Watteau, Fragonar e Boucher ${ }^{6}$ foram, a seu tempo, ardentes protetores e precursores da ideia de ornar as casas com pinturas artísticas. Esses três pintores puseram a riqueza de sua genialidade criativa a serviço da decoração de casas particulares e aristocráticas. Não era de se estranhar que a arte decorativa francesa daquela época tenha se imortalizado, assinalada por incontestável valor. Depois dos três, vieram discípulos e continuadores que levaram a arte decorativa a inúmeros lares abastados. O papel pintado, como noutras eras, começou também a despontar. Sendo barato, muitas pessoas utilizavam-no com profusão, ornamentando os grandes e elegantes salões. Além do papel, o mosaico foi bem aceito no lar moderno. Recordando a cerâmica romana, trazia um caráter exótico com suas paisagens, flores e animais cubistas ou impressionistas.

Sem dúvida, essa classe de adereçamento tinha algo de inocente e simples, capaz de se harmonizar com a habitação de caráter íntimo e familiar. Nas salas de estar reinava a completa simplicidade em móveis e detalhes. No entanto, os móveis eram extravagantes, práticos e "chiques". Telas luminosas e cortinas em abundância completavam o conjunto, em que lãs, couros, tecidos finos com flores recortadas, veludos, etc. traziam a comodidade e simpleza esperadas ${ }^{7}$.

Finalmente, ao final do decenário, o predomínio da nova escola modernista era geral, e o modernismo conseguiu triunfar vigorosamente no mobiliário. Os móveis sofreram radicais transformações, com linhas inéditas, arrojadas e desenhos em estilo cubista, nunca vistos. A concepção era inrrefutavelmente original, mas nem sempre considerados belos; exceto nos banheiros, pois a inovação se fazia presente nesse compartimento luxuoso e atraente, com suas banheiras em alabastro ${ }^{8}$ colorido e per6 No século XVIII, Antonie Watteau, Jean Honoré Fragonard e François Boucher foram pintores franceses do movimento roco7 VIDA DOMÉSTICA, Rio de Janeiro, Edição 00094, nov.1925.

8 "Pedra calcária ou gipsífera finamenta granulada, translúcida e esbranquiçada, de fácil polimento, e com a qual se fazem lustres, esculturas, peças de adorno. De aspecto semelhante ao do mármore, não possui a mesma resistência deste." (MOUTINHO, 2011, p. 7). 
tences condizentes na cor, e que se ampliava em direção aos reposteiros ${ }^{9}$, vitrais e peças de mobiliário ${ }^{10}$. Antes, no início dos anos 1920 , as salas de banho deviam ser todas em branco: forradas com faiança branca, teto esmaltado de branco, mosaicos brancos. Admitia-se quebrar a lisura do branco com um friso azul na orla da barra da parede com motivos frescos (moinhos holandeses, flores aquáticas, aves riscando o céu enquanto voavam). O luxo da sala de banhos advinha do aperfeiçoamento e comodidade de seus aparelhos, do brilho pálido de seus cobres e da limpeza das bacias de mármore ou de porcelana inglesa. Além disso, o espaço compunha-se de um esquentador, de um chuveiro, de um bidet com água corrente e um tubo para as duchas de mão. Fora os aparelhos, necessitavam de um grande espelho, um cabide para a roupa de tecido, um esquentador para toalhas em metal niquelado e uma chaise-longue para as massagens. Um armário de vidro sobre a parede devia conter luvas de fricção, sais e frascos de pós de amido. ${ }^{11}$

\section{O espírito moderno da arte decorativa}

Em 1924, na Exposição Bienal de Arte Decorativa de Monza, objetos em profusão, representando a cultura de cada região italiana, indicavam que a antiga tradição artística não tinha sido sufocada pelo modernismo considerado "invasor". Entre inúmeros artigos, os mostruários da secção cerâmica e porcelana abrigava os mais variados objetos de louça, desde a mais longínqua faiança à mais requintada porcelana (Ilustração 01). Além das afamadas localidades italianas (Veneza, Mondovi, Doccia, Calabria, Sardenha e Faenza), achavam-se representados a China, o Japão, a Romênia, a Polônia e a "Tcheco-Eslovaquia".

\footnotetext{
$9 \quad$ "Cortina de tecido ou outro material pendente das portas internas ou de outros vãos." (MOUTINHO, 2011, p. 377).

10 VIDA DOMÉSTICA, Rio de Janeiro, Edição 00138, set.1929.

11 A VIDA MODERNA, São Paulo, Edição 00379, p. 26, 25.mar.1920.
} 


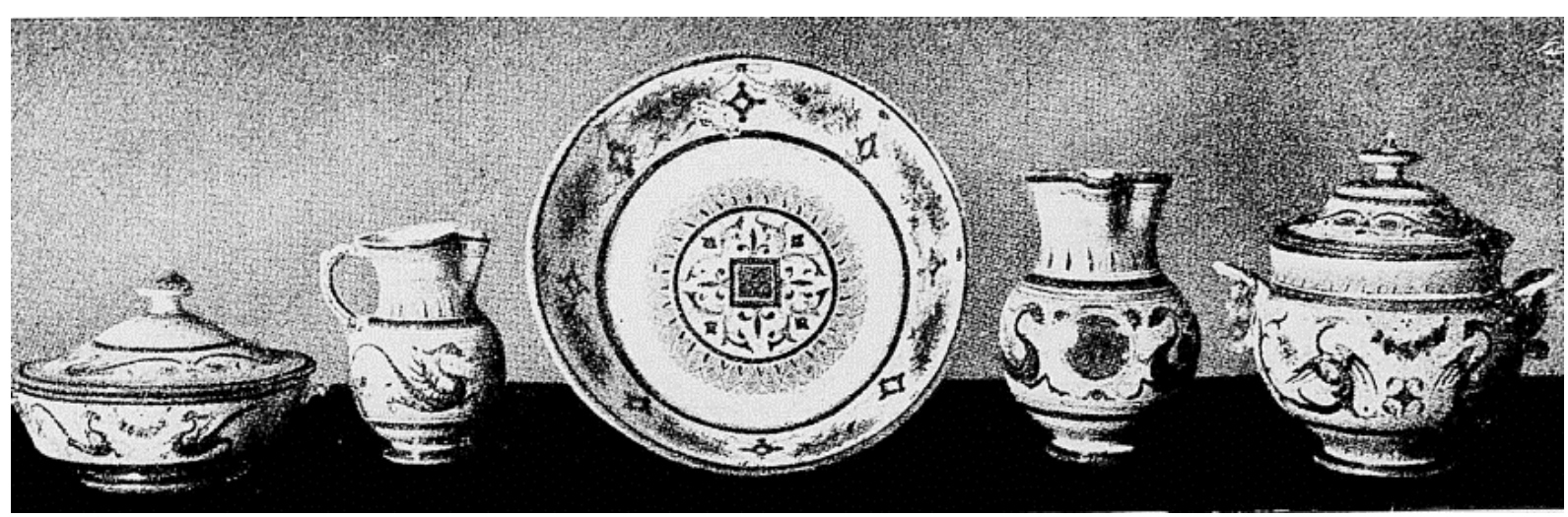

ILUSTRAÇÃO 01 - LOUÇA DE DERUTA FEITA À MÃO COM VÁRIOS MOTIVOS RAFAelESCOS. FONTE: VIDA DOMÉSTICA, RIO DE JANEIRO, JUN.1924.

Os trabalhos italianos, muitas vezes executados no gênero setecentesco, eram obras de artistas renomados, escultores e engenheiros, os quais se mantinham fiéis à escola longeva, mas introduzindo, por vezes, algum modernismo que reforçasse o bom gosto sem alterar a linha. Mesmo porque, várias secções da Exposição de Monza, especialmente as de Roma e entorno, apresentavam produtos industriais primorosos advindos da escola moderna. Os objetos, móveis e decorações de parede desses mostruários revelavam uma imaginação fecunda dos artistas em concepções cujas linhas nada tinham que recordassem a arte pregressa ${ }^{12}$. Na verdade, a exposição revelou uma das mais belas demonstrações da pujança artística da Itália, atestada pela quantidade de estandes, donde era possível apreciar as modernas tendências de cada uma das regiões da península ${ }^{13}$.

No entanto, o que demonstrou claramente a existência de um estilo novo, confirmando a vitória de um espírito modernista, foi a Exposição das Artes Decorativas de Paris de $1925^{14}$. Os diferentes estilos avoengos deixariam na arte um sentimento pleno de simplicidade e equilíbrio, porém, a Arte Moderna excluiria de si esses estilos "decadentes" e todas as imitações da Arte Antiga criadas remotamente por artistas que eram mais apreciados pela sua habilidade profissional, do que pelo bom gosto e originalidade. A exposição de Paris demonstraria a existência de um estilo inédito e completamente novo, manifestando-se em objetos, adornos, móveis, ambientes e arquiteturas. ${ }^{15}$

\footnotetext{
12 VIDA DOMÉSTICA, Rio de Janeiro, Edição 00077, jun.1924.

VIDA DOMÉSTICA, Rio de Janeiro, Edição 00079, ago.1924.

Revista A Casa, Rio de Janeiro, Edição 0063, p. 15, jul. 1929.

VIDA DOMÉSTICA, Rio de Janeiro, Edição 00101, jul.1926.
} 
No Brasil, essa tendência moderna foi bem aceita e a arte decorativa se tornou necessária nas preferências domésticas da casa, todavia precisava ser proposta e realizada por artistas renomados. Foi o caso dos trabalhos murais do escultor Roberto Lacombe que versava sobre estilizações dos elementos da flora brasileira nas superfícies de tetos e paredes. A decoração mural requeria reflexão e gosto esmerado por parte daquele que propunha executá-la. A coloração e as tonalidades desempenhavam papel preponderante no bom aspecto do compartimento, mas, quando determinadas arbitrariamente, produziam um efeito ruim sobre o mobiliário. Por isso, a escolha cuidadosa da ornamentação devia ficar a cargo de um profissional conhecedor da sua arte para não trazer sensações brutais ao ambiente.

Outra aplicação da arte decorativa amplamente adotada no Brasil envolvia os vitrais coloridos. Exercendo grande influência nos edifícios que adornavam, se fossem mal compreendidos, podiam comprometer os efeitos das formas arquitetônicas, porém conseguiriam realçá-las se concebidos inteligentemente. Como qualquer outro gênero de pintura, o vitral exigia composição simples e sóbria, não se limitando à imitação rigorosa do real. Excluindo a ilusão de perspectiva, o objetivo era atrair a atenção do observador com uma coloração franca, enérgica e com poucos tons, buscando equilibrar a suntuosidade com a calma. Comparável a um mosaico mural ou aos esmaltes da ourivesaria que floresceram entre os séculos XII ao XIV, ou à tapeçaria oriental, o vitral decorativo não tinha analogia com a pintura artística, representando cenas ou paisagens através da janela onde a atenção se concentraria mais num ponto do que no conjunto. Nos anos 1920, afirmava-se que a lei fundamental da pintura decorativa repousava sobre uma convenção estabelecida para a satisfação da vista, que se contenta mais com a decoração racional de uma construção do que a sensação da realidade. Existia, assim, um abismo entre um vitral e um quadro. Ao tentar a transposição dessa lei, a escola moderna, herdeira da Renascença Italiana, desviou a arte decorativa do caminho que the havia traçado o bom senso. ${ }^{16}$ 


\section{Os estilos vigentes nos anos 1920}

Com o propósito de se mobiliar uma casa com elegância, fazia-se necessário ter noção de arte decorativa e, obviamente, dos estilos vigentes. Em meados do decênio de 1920, os estilos mais correntes em móveis eram Renascença, Luís XIII, Luís XIV, Luís XV, Luís XVI, Império e Moderno.

Destes, o estilo Renascença foi o primeiro que apareceu bem caracterizado, definido, transformando o móvel em verdadeira obra de arte, ornado de colunas e figuras cariátides e festões. As figuras nuas ou seminuas recordavam a pureza de linhas da antiguidade, enquanto os arabescos e caríatides das pilastras e colunas evocavam os tempos da arte grega. A cama era de exagerada dimensão, em madeira esculpida e coberta de brocado. ${ }^{17}$ As tapeçarias assemelhavam-se às italianas quase totalmente cobertas de paramentação. A cerâmica, as baixelas, os candelabros e os bibelôs de prato eram similarmente inspirados nos motivos italianos.

Quase todos os móveis de Luís XIII eram em ébano com formas quadrangulares e linhas diretas, porém confortáveis. As cadeiras eram de couro gravado ou estampado, e as camas baixas com colunas guarnecidas de custosas cortinas. Vale notar que as damas de destaque e as altas personalidades daqueles dias tinham o leito no salão principal da casa. No ataviamento dos objetos usuais, o estilo Luís XIII não imprimiu sua característica, sendo raros os bibelôs.

Já o estilo Luís XIV demonstrava uma notável unidade entre a pintura, a arquitetura e o mobiliário, composto de poucas peças, sendo que o conforto era sacrificado em prol da estética. Configurava-se pela poltrona larga de proporções sabiamente calculadas, os traços e os pés igualmente esculpidos, cobertos de ricas tapeçarias. As mesas majestosas, douradas e profusamente guarnecidas de mosaicos, o console apoiado na parede com os pés cobertos de motivos da arquitetura, as cômodas de aspecto rude e as escrivaninhas solenes. A cama sempre larga e baixa, geralmente sem colunas. Uma das características do estilo era o emprego de marchetaria com madrepérola e marfim. Era um estilo sério.

17 "Rico tecido decorativo feito de seda e realçado por desenhos em relevo, não raro enriquecidos com fios de ouro e prata; muito usado na indumentária, foi também aplicado à decoração a partir do séc. XVII." (MOUTINHO, 2011, p. 329). 
Marcado por linhas curvas e ausência de retas, o estilo Luís XV era bastante faustoso em relação aos anteriores, com alguma coisa da derradeira Renascença. Associado à elegância e frivolidade da mulher, tudo era aparatado, esculpido, gravado e cinzelado. As camas diminuíram de tamanho, a luz tornou-se mais intensa e discreta, os móveis mais cômodos. Grandes quadros e pesadas tapeçarias cobriam as paredes, os espelhos eram abundantes, o ouro e o branco cobriam os tetos, os móveis eram revestidos com Vernis Martin ${ }^{18}$ e lacas do Oriente. Os bronzes cinzelados e as porcelanas da Saxônia e da China apareceram de maneira requintada e harmoniosa por toda a parte. As peças da casa a recebê-los, foram o salão, o toucador, o quarto e a sala de jantar. Os leitos cobriam-se de colchas de seda e o luxo chegou ao extremo. Para complementar, o rococó foi o estilo Luís XV atribuído à Madame de Pompadour. As linhas eram coerentes e menos extravagantes, com uma desordem graciosa na acumulação de objetos preciosos.

O estilo Luís XVI fez da mobília verdadeira obra-prima. Era uma combinação de antiguidade e Renascimento com tendência ao gosto elegante, enriquecido pelo acatamento da mão de obra, o que concorreu para que os bibelôs e os móveis fossem pagos a peso de ouro. O mobiliário era envernizado ou pintado, com adereços de bronze, trabalhado com grande habilidade e bom gosto. Os móveis grandes eram ligeiramente côncavos, os puxadores de cobre ou dourados eram vistosos. Os ornatos e as guirlandas apareciam como motivos obrigatórios juntamente com os fios de pérolas, até nos candelabros. A linha reta era a característica do estilo, com as aplicações de espigas, de liras, acantos e laureis. Nesse tempo, apareceram as porcelanas de Sévres, ${ }^{19}$ assim como os biscuits, ${ }^{20}$ marfins, lacas e bronzes orientais. A madeira dourada a fogo desapareceu para dar lugar aos móveis de cores suaves, branco, azul e rosa. Em relação aos tecidos, pertenciam à época, os quadros em seda com tintas desmaiadas e os cretones $^{21}$ indianos coloridos. O estilo atingiu o apogeu da arte decorativa.

\footnotetext{
18 "Designação genérica de um tipo de falsa-laca usado na Europa setecentista para a pintura de móveis, boiseries, carruagens, clavicórdios, leques, caixas, etc. 9. [...] Depois de muitas experiências no séc. XVIII, na França, os irmãos Martin conseguem, com elementos diversos daqueles usados pelos orientais, um verniz 'a maneira chinesa' que serve de fundo a delicados desenhos em especial a chinoiseries." (MOUTINHO, 2011, p. 469).

19 "A mais importante manufatura de porcelana da França, ainda em atividade e que impôs o alto padrão de seus produtos ao mercado europeu aproximadamente entre 1760 e 1815." (MOUTINHO, 2011, p. 403).

20 "Porcelana branca fina cozida ao forno duas vezes e não vidrada, e que, pela delicadeza da textura, é usada na fabricação de estatuetas, bibelôs, medalhões, etc. As possibilidades decorativas do biscuit foram aplicadas pela primeira vez em Sèvres [1753]. Essa porcelana presta-se para a reprodução de esculturas antigas ou outras." (MOUTINHO, 2011, p. 50).

21 Conhecido também por bramante, o cretone é um tecido encorpado, feito de algodão ou linho, com uridura de cânhamo. Serve para confeccionar colchas, cortinas e tapeçarias.
} 


\section{Arranjos domésticos brasileiros testemunhados por periódicos da década de 1920}

O Império foi um estilo que propôs a volta à idade romana ou etrusca, cópia servil desvirtuada pela abundância de quadros, papéis pintados, tapetes, bronzes e cristais. A severidade das linhas chegava à monotonia pela falta de variedade, como se todos os fabricantes estivessem sob as ordens de uma única pessoa. A ausência absoluta de fantasia e o frequente abuso de traços geométricos elementais davam rigidez aos desenhos. Abuso também de figuras desconhecidas, monstruosas e das palmas cruzadas. Adotou-se como regra a madeira em acajú, ${ }^{22}$ com incrustações de bronze. As camas eram baixas, cobertas de pesadas cortinas.

O último estilo a ser abordado é o moderno. Diga-se de passagem que esse estilo se inspirou em quase todos os supracitados, aproximando-se mais do estilo Luís $\mathrm{XVI}$, com uma grande influência oriental. As formas ligeiras, as linhas retas, a harmonia e riqueza do colorido com tonalidades suaves, caracterizariam esse estilo. Admitia o ecletismo e todos os caprichos da fantasia, todas as invenções e todas as combinações. Predominavam os motivos da arte japonesa e árabe, combinados com a civilização europeia. $^{23}$ No mobiliário moderno em particular, sem desprezar o efeito decorativo, tudo devia se revestir de utilidade e conforto. Considerando os recursos de comodidade e higiene, era fundamental levar em conta o destino de cada peça no arranjo do lar, haja vista que o tamanho reduzido de muitas casas fazia com que os cômodos se transformassem continuamente (uma sala de jantar poderia virar uma sala de recepção). Por isso, dominar a arte da mobiliação era tão importante. ${ }^{24}$ Aliás, de acordo com as palavras de Aprígio Gonzaga, especialista responsável pela seção "O Arranjo do lar” do periódico Revista Feminina de 1921, "o arranjo da casa [é] uma verdadeira ciência, com os seus problemas, regras e corolários, princípios e objetos. O objeto é a felicidade e os princípios se resumem num só - fazer o lar agradável e sadio." Para ele, quem fazia a casa era o morador, não quem a construia. ${ }^{25}$

Talvez por isso, as noções sobre estilos facilitaria o processo geralmente requerido à dona de casa. Não obstante, reconhecia-se a dificuldade em estabelecer regras, pois nem todas as habitações comportavam um mobiliário que seguia rigorosamente

\footnotetext{
22 "Designação comum a diversas madeiras de cor avermelhada, entre elas o mogno." (MOUTINHO, 2011, p. 3). VIDA DOMÉSTICA, Rio de Janeiro, Edição 00095, dez.1925.

A VIDA MODERNA, São Paulo, Edição 00494, p. 35, 3.abr.1925.

REVISTA FEMININA, São Paulo, Edição 089, ano VIII, p. 17, out.1921.
} 
um estilo. A casa moderna pequena, guarnecida com as peças estritamente necessárias, admitia o mobiliário no estilo alemão ou norte-americano, talhado em linhas retas, com ornamentação de cretone. Já o bungalow teria um mobiliário próprio, armários nas paredes, peças embutidas no lambril ${ }^{26}$ da sala de jantar e no fumoir (sala para fumantes), sempre de acordo com as regras de conforto norte-americanas. ${ }^{27}$

A decoração interior pedia, portanto, grande atenção porque comportava muita fantasia e inovação que não deviam ser banalizadas para não caírem no ridículo. Estava totalmente a cargo do bom gosto e da inteligência de quem iria guarnecer o espaço; qualidades essenciais para se ter a casa mobiliada com arte. A simplicidade e a discrição eram indispensáveis, devendo se refletir em móveis imprescindíveis e que possuíssem verdadeira propriedade. Todavia, àqueles cuja dificuldade em adornar os ambientes domésticos parecia ser algo insuperável, podiam contar com serviços encomendados e que eram anunciados periodicamente em revistas especializadas. Era o caso de Otto Schütte Filho que projetava e fabricava mobiliários e decorações para então chamada "arte interior" (Ilustração 02). ${ }^{28}$

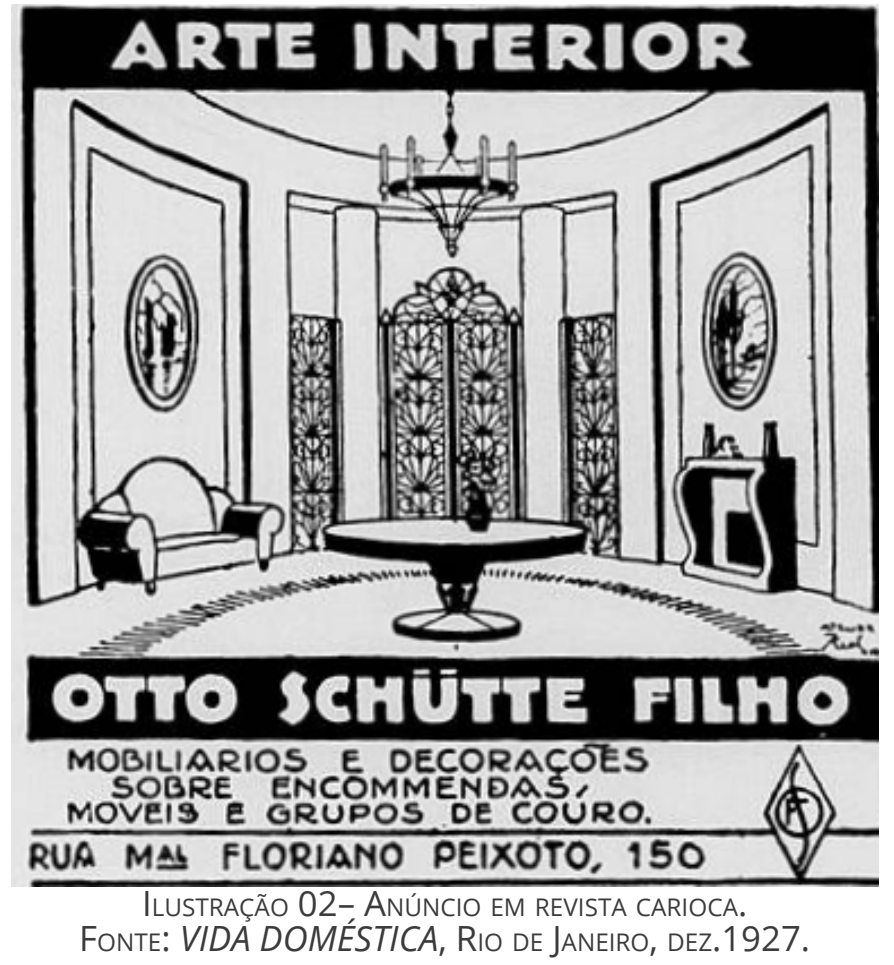

\footnotetext{
$26 \quad$ "Revestimento de paredes internas com madeira, aplicado até certa altura." (MOUTINHO, 2011, p. 241)

28 VIDA DOMÉSTICA, Rio de Janeiro, Edição 00117, dez.1927.
} 


\section{O moderno e as inovações do lar}

O progresso da medicina foi um dos agentes a influenciar na simplificação do mobilar, pois esperava-se facilidade na limpeza do mobiliário, sem buracos ou asperezas onde se repousasse a poeira. Por essa razão, o material adequado aos móveis modernos compreendiam linhas arredondadas, superfícies lisas e madeira aplainada coberta com verniz, pátina ou com uma camada de pintura clara. Esperava-se, antes de tudo, que o domicílio recebesse móveis qualificados em dar uma impressão de frescura e alegria ao ambiente. Nesse sentido, a nudez da madeira branca das janelas sobriamente paramentadas, como ocorria numa casa rural, era a vantagem incontestável da moderna arte de mobilar. A inovação dos lares modernos tendia, assim, à substituição dos objetos de metal por aqueles de madeira, além de permitir que os móveis fossem enfeitados com bibelôs, o que trazia uma simplicidade não permitida em finais do século XIX.

Dito isso, pergunta-se: o que se entendia por "moderno estilo" na mobiliação? Nos anos 1920, acreditava-se erroneamente que o conceito modern style resultava da importação em bloco de elementos decorativos estrangeiros. Na verdade, o modern style, adaptado e modificado pela produção nacional, deu provas do bom gosto e, por consequência, teve a aceitação do público. Os móveis modernos, salvo algumas exceções, distiguiam-se pela simplicidade intencional, quase ingênua de sua forma. Após uma longa busca no decurso dos séculos, o conforto, a elegância, o luxo e o refinamento extremo do detalhe dariam lugar à madeira branca natural talhada quase à faca, com veios e nós evidenciados, e um sadio odor resinoso. Caracterizava-se, dessa maneira, a ascensão de um requinte fundamentado na sobriedade deliberada e na capacidade de dominar o mesmo motivo de adereçamento em todo o conjunto da peça. Um quarto em tom verde-mar ou violáceo necessitava, por exemplo, harmonizar-se com os móveis e pinturas murais; flores como íris ou glicínias estilizadas poderiam fornecer o tema ideal ao aparatar estojos, frisos e guarnições do toilette; e a afirmação da simplicidade elegante poderia ser consolidada por conjuntos em estilo rústico assinados por artistas decoradores renomados. ${ }^{29}$ 
Hábitos modernos remodelavam, mas também reinventavam ambientes. Recorrente em revistas especializadas desde princípios dos anos 1910, o fumoir ou sala de fumo era um pequenino reino, um aposento viril d'avant-guerre destinado ao marido. Esta peça da casa requeria um ambiente pleno de originalidade e fantasia sustentadas pela arte e pelo bom gosto. Com o advento da arte moderna, a expectativa era que essa renovasse inteiramente o aspecto do lugar. A cor havana e seus nuances simbolizavam modernidade, desde a mais pálida à mais quente tonalidade, e podiam ser harmonizados com madeiras de cor mediana; já os móveis não tinham atribuições tão bem definidas, por isso variavam de baús esculpidos a pequenas etagères; e os assentos precisavam ser profundos e flácidos, com compridos divãs e largos fauteuils com profusão de almofadas. O centro do aposento devia ser ocupado por uma grande mesa sobre a qual estariam acomodados diversos utensílios para fumantes. Fora do estilo moderno, estofos e tapetes do oriente eram bem vindos. ${ }^{30}$ Ainda que mantivessem veludos ricos e quentes, espessos tapetes e confortáveis fauteuils, as propostas do espaço se modernizaram alguns anos depois com o feminismo incipiente e, no final da década, começou-se a confeccionar cocktails apreciados igualmente por mulheres. Em teoria, naqueles anos de "progresso", a "cigarrilha" deixou de ser algo exclusivamente masculino (Ilustração 03). ${ }^{31}$

Essas novidades advindas da Europa reforçavam a predisposição ao estrangeirismo, o que incluia a manutenção dos termos adotados internacionalmente no Brasil. Citando um caso correspondente, naqueles anos, muitas propriedades rurais da Inglaterra eram consideradas acolhedoras em virtude do hábito de adotar bob-windows: três janelas guarnecidas de vitrais em cores diferentes que avançavam da fachada, criando um refúgio íntimo (llustração 04). Geralmente, eram ornadas com cortinas vistosas e floridas com trepadeiras. Este hábito se disseminou no Brasil, primordialmente em casas modernas do Rio de Janeiro, tanto nas cidades quanto nas cercanias. Parecia-se com um balcão fechado a avançar sobre a rua. Na cidade, sua dimensão era reduzida e acomodava dois fauteuils e uma pequena mesa para o café. Guarnecido como um jardim de inverno, esse anexo domiciliar parecia prolongar o compartimento. No campo,

$30 \quad$ A VIDA MODERNA, São Paulo, Edição 00375, p. 20, 29.jan.1925.

31 VIDA DOMÉSTICA, Rio de Janeiro, Edição 00138, set.1929. 
o bob-window assumia dimensões mais avantajadas, a ponto de se transformar numa pequena peça (num studio-sala, num atelier, num fumoir ou mesmo num quarto de dormir). Recomendava-se a simplicidade. ${ }^{32}$

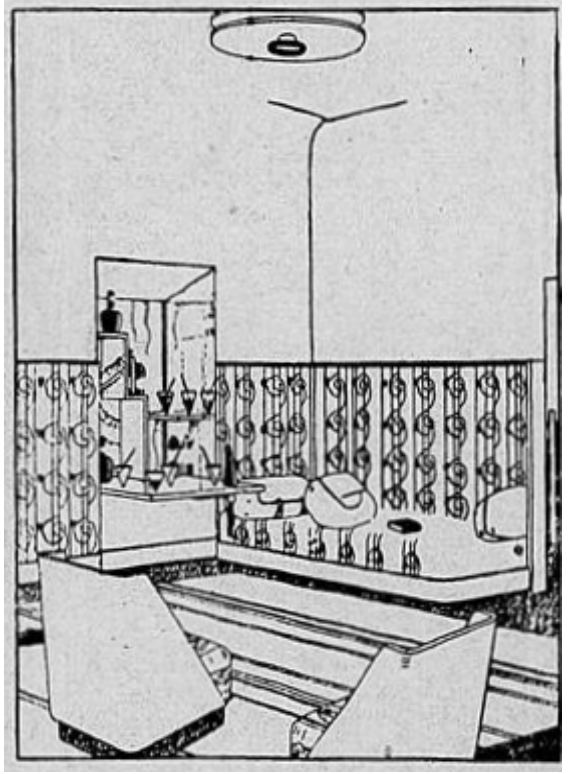

ILUSTRAÇÃO 03 - FUMOIR PROJETADO POR ERIC BAFFE E DECORADO POR LUCIEN BOUIX. FONTE: VIDA DOMÉSTICA, RIO DE JANEIRO, SET.1929.

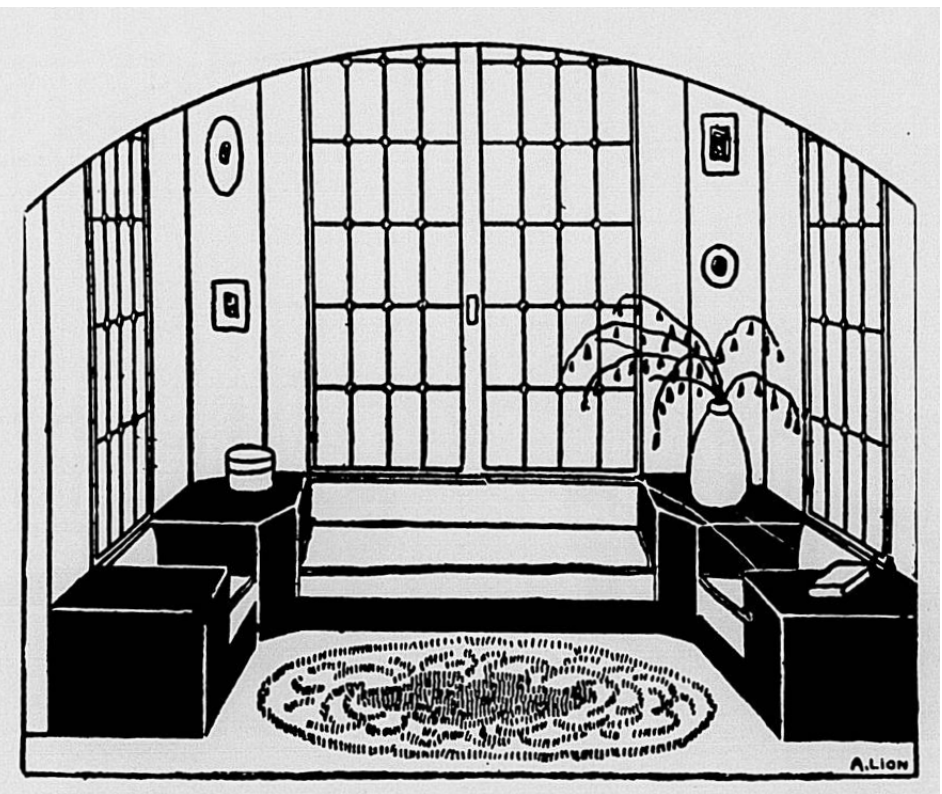

ILUSTRAČ̃̃O 04 - BOB WINDOW.

FONTE: VIDA DOMÉSTICA, RIO DE JANEIRO, ABR.1929.

Outro elemento inovador da ambientação do lar e usado como um verdadeiro recurso decorativo foi a luz. Um abat-jour opaco de forma cônica e achatada, por exemplo, era capaz de rebater vivamente a luz que se distribuía sobre o elemento abaulado. Isso demonstrava que a luz poderia ser manipulada como se fazia com a cor, procurando criar atmosferas mais intimistas com um refinamento exótico. Nesse particular, trouxeram de volta as velhas luminárias de outrora em paralelo a inspirações sanitárias inusitadas, como as bolas de vidro impregnadas de líquido colorido, similares àquelas vistas nas vitrines farmacêuticas. ${ }^{33}$

\section{Quem fazia e quem vendia?}

Uma das casas de venda recomendada pelas propagandas de revistas especia\begin{tabular}{ll}
\hline 32 & VIDA DOMÉSTICA, Rio de Janeiro, Edição 00133, abr.1929. \\
33 & VIDA DOMÉSTICA, Rio de Janeiro, Edição 00133, abr.1929.
\end{tabular} 
lizadas no lar, encontrava-se, no Rio de Janeiro. Tratava-se da importadora Casa Santos situada à Rua Sete de Setembro, $\mathrm{n}^{\circ}$ 82, propriedade dos Srs. Antônio Gomes dos Santos Júnior \& Cia. Essa empresa fornecia mobiliários insólitos, tapetes, capachos, tecidos para mesa e colunas, stores, tapetes de linoleum, oleados para mesa e para forrar salas, etc. Entretanto, naqueles anos, a sobrepujança era o mobiliário de vime e junco, porque, além de importadora, o estabelecimento tinha uma indústira abastecida com oficinas que produziam semanalmente, exemplares e modelos de móveis dessa tipologia (Ilustração 05). ${ }^{34}$

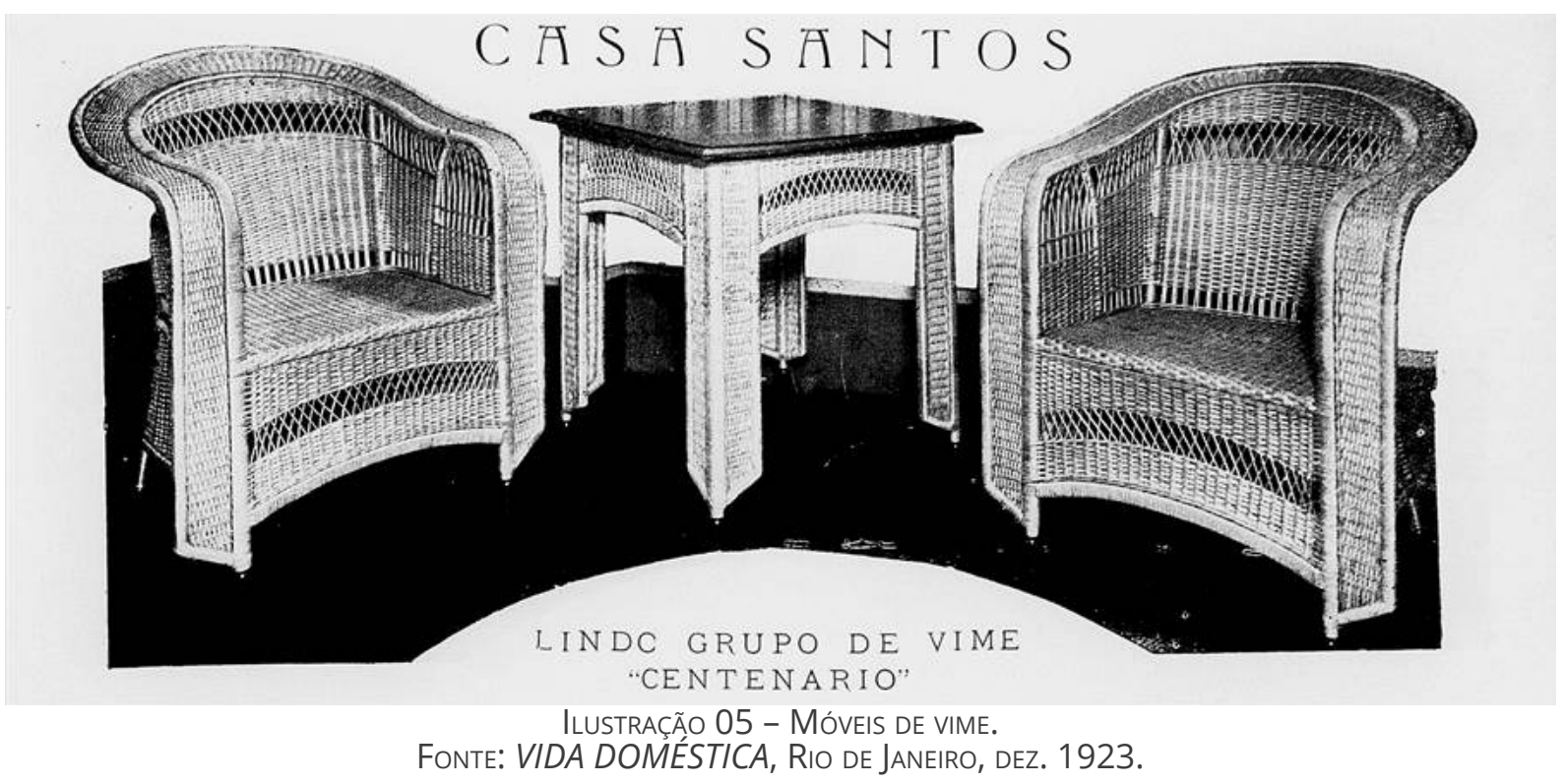

Outro produto estrangeiro admitido amplamente nos lares brasileiros foi o fogão alemão a gás Homann distribuido pela Herm. Stoltz \& Co. ${ }^{35}$ Era costume pensar que tudo que se fazia no exterior era melhor e mais bem feito daquilo que se produzia no Brasil.

No tocante às superfícies da casa, devido às características sanitárias, o linóleo foi um revestimento largamente solicitado no decênio de 1920. Das empresas que comercializavam o produto, destacou-se a Congoleum Company of Delaware que comercializava o soalho Belfor Inlaid Linoleum, um mosaico de linóleo ligado a uma tela de cânhamo, tanto no Rio de Janeiro como em São Paulo (Ilustração 06). Os padrões do artigo não eram pintados, senão embutidos, e a instalação era da responsabilidade dos \begin{tabular}{ll}
\hline 34 & VIDA DOMÉSTICA, Rio de Janeiro, Edição 00068-00069, dez.1923. \\
35 & VIDA DOMÉSTICA, Rio de Janeiro, Edição 00124, jul.1928.
\end{tabular} 
técnicos da empresa. Seguindo um desempenho similar a outro produto da empresa, o Gold Seal Linoleum liso, amortecia o ruído dos passos e era confortável, higiênico e durável. Ademais, exercia um papel importante na decoração de interiores modernos. ${ }^{36}$

Em definitiva, vale evidenciar um produto tipicamente brasileiro. Muito presente nas moradias do país, desde princípios da década de 1910 que a divulgação do filtro Fiel se tornou uma constante nos periódicos especializados. A importância desse produto de fabricação própria foi tamanha que consagrou o estabelecimento Casa Fiel internacionalmente. Pioneira na modernização do comércio de barros, o produto era um higienizador de água premiado em todas as exposições em que concorreu. Em 1926, obteve a mais alta recompensa conferida naqueles anos: a Cruz de Mérito, em Milão (Ilustração 07). A Casa Fiel J.R. Nunes \& Cia., situada no Rio de Janeiro (na estação do Riachuelo, à Rua 24 de Maio, n 162), comercializava também louças, porcelanas, bronzes, cristais, bibelôs e artigos finos, quer sob o ponto de vista artístico, ou de utilidade. $\mathrm{O}$ estabelecimento mantinha ainda um armazém de madeiras e materiais para construção. ${ }^{37}$

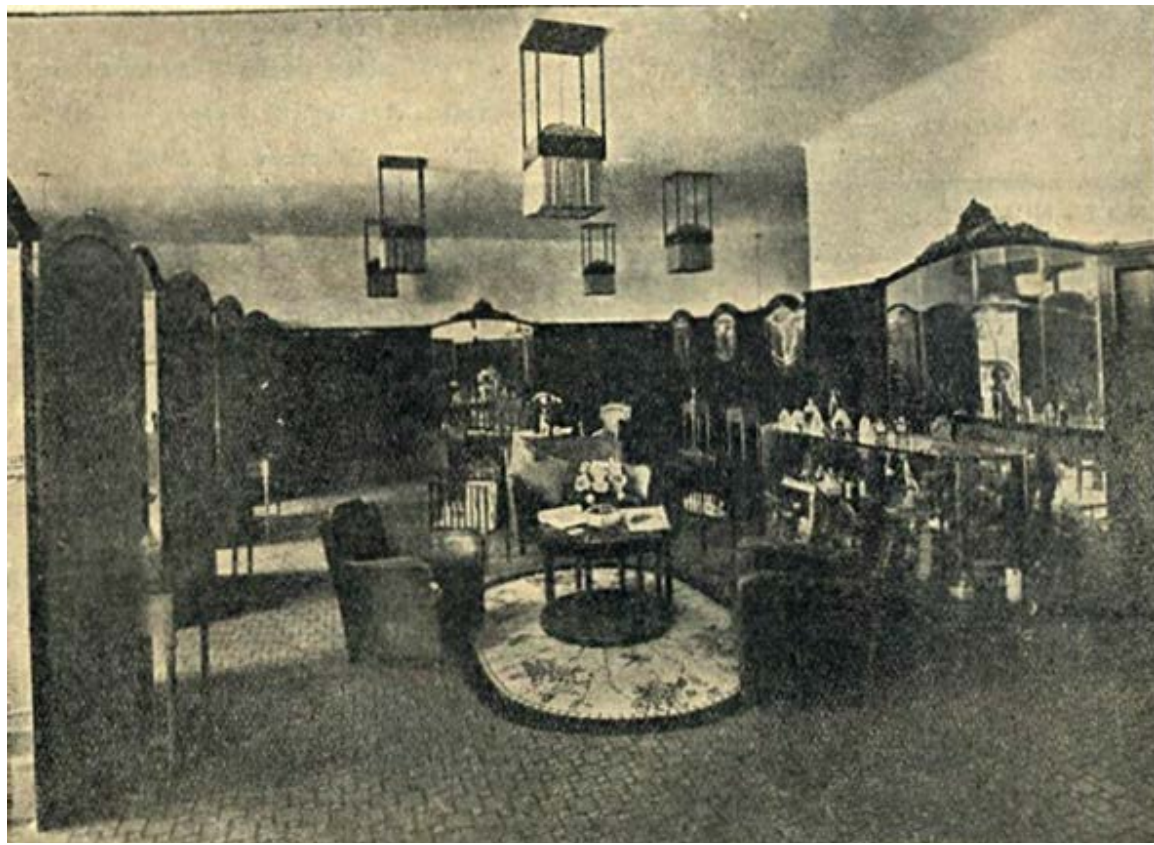

ILUSTRAÇ̃̃o 06 - SOALHO dE LINÓLEO APLICAdO NO SALÃO DE BELEZA DA CASA MAPPIN Stores. Fonte: VIDA DOMÉSTICA, RIO DE JANEIRO, JAN. 1927.

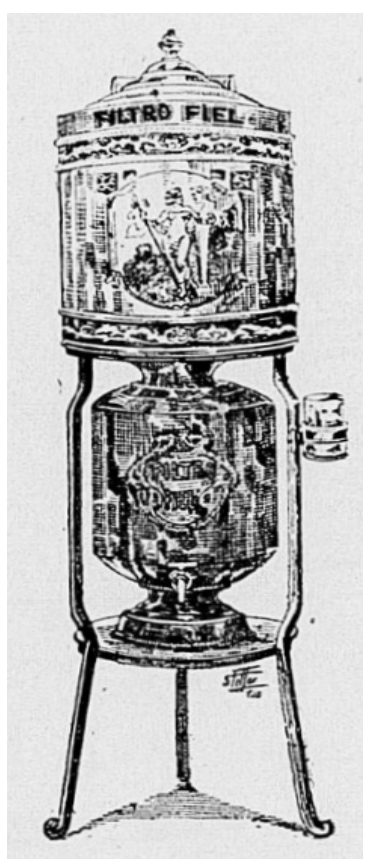

ILUSTRAÇÃO 07 - FILTRO DE ÁGUA PREMIADO EM MILÃO, DA MARCA FIEL. FONTE: VIDA DOMÉSTICA, RIO DE JANEIRO, NOV. 1925.

36 Revista A Casa, Rio de Janeiro, Edição 0033, p. 08, jan. 1927.

37 VIDA DOMÉSTICA, Rio de Janeiro, Edição 00106, dez.1926. 


\section{O lugar das coisas nos arranjos domésticos}

Em junho de 1927, sob os cuidados da especialista em arranjos domésticos Joanna Brandt, a revista Vida Doméstica iniciou em suas páginas a secção "Arte Decorativa - Como mobilar e decorar" com o propósito de orientar a arrumação do lar em conformidade com as tendências em voga. Imaginando uma casa ideal, as informações que discriminavam o processo eram assaz detalhadas, que procuramos manter a descrição integral de dois compartimentos sociais selecionados: o living-room e a sala de jantar; e acrescentamos a descrição de uma cozinha para ilustrar a zona de serviços.

Segundo Brandt, no processo de mobiliação, o elemento principal a se ter em mente era a harmonia. Buscando equilibrar proporções e tonalidades, evitava-se exageros que revelassem um gosto "fraco e medíocre". Ao se idealizar um conjunto, a prudência recomendava pensar no espaço em concomitância às áreas contíguas. Isso daria uma continuidade ao ambiente, impedindo o amalgamar de gostos considerados opostos. Vencidas as dificuldades preliminares provenientes das proporções e dimensões difícieis, o passo seguinte seria resolver o caráter do cômodo em questão e a combinação de cores que comprazeriam aos futuros habitantes, a fim de se obter um cunho individual. ${ }^{38}$

\section{Living-room}

Tomando-se por base uma área com $6 \mathrm{~m} \times 5 \mathrm{~m}$, a descrição que segue corresponde a um living-room moderno idealizado, a parte da casa onde as pessoas passavam horas de descanço durante o dia e recebiam suas visitas familiares. Os móveis confortáveis e um tanto pesados harmonizados com objetos de arte, bons quadros, flores e plantas, faziam desse local a sala principal da residência e não um lugar hermenêutico que mantinha os móveis cobertos por capas brancas, e cujas portas somente se abriam quando as visitas de cerimônia entravam.

No referente à combinação de cores, a recomendação era escolher tons dis-

$\overline{38}$

VIDA DOMÉSTICA, Rio de Janeiro, Edição 00111, jun.1927. 
cretos para as paredes, por exemplo, um gris de tonalidade média ou liso, de aspecto aveludado ou com um desenho ton sur ton, ou listras finas de ouro velho fosco, ou outros ornatos em ouro. Um papel gris com desenhos delicados em lilás caia bem, ou por outra, gris e lilás poderiam ser as cores escolhidas como as dominantes na decoração do arranjo doméstico. Um grupo de móveis estofados do gênero Chesterfield ${ }^{39} \mathrm{com}-$ posto por duas ou três poltronas no mesmo gênero e algumas cadeiras em estilo antigo, era o suficiente em termos de assento. O grupo seria forrado com veludo lilás escuro, ao passo que as cadeiras poderiam ser de seda adamascada da cor do desenho gris sobre lilás; ou vice-versa com as cadeiras de madeira esculpidas com alto espaldar e assentos de seda adamascada, lilás ou gris com fios de ouro velho no tecido.

O sofá seria colocado com as costas voltadas para a janela bay-window larga;40 entre esta e o sofá, colocar-se-ia uma mesa de oitenta centímetros ou mais da mesma espécie do sofá. Tanto esta mesa como outras duas ou três menores deviam, se possível, adaptar-se ao estilo das cadeiras vetustas. Uma das mesas precisava ser mais baixa e posicionada em frente ao sofá, outra encostada a uma das poltronas e, por fim, outra junto às poltronas ovais. Este seria apreçado como um grupo harmonioso. Da terceira mesa poderia ser composto, em um canto, um grupo muito delicado, constituído pela mesa, as cadeiras antigas e uma vitrine, ${ }^{41}$ na qual encerrariam as preciosidades e recordações da família, a saber, bibelôs finos e outros objetos de cunho pessoal. E ainda poderia ser reservado um lugar na sala para o piano de cauda acompanhado do banco forrado com veludo lilás escuro e um pequeno armário para música, tudo no mesmo estilo que o piano.

O tapete era muito importante. Esperava-se que tivesse o recorte de uma cor lisa em gris ou lilás, com uma expressiva cercadura apta a incorporar outras cores que se harmonizassem com o conjunto, como por exemplo, vieux-rose (um tom de rosa envelhecido), preto, branco, ocre, verde-oliva, ouro-velho e outras. As cortinas de xan-

\footnotetext{
39 Poltrona baixa, inteiramente estofada, conhecida na época apenas como Maple que era o nome da empresa londrina responsável pela exportação desse tipo de assento para Portugal. Segundo Moutinho (2011, p. 89), era um "tipo de sofá amplo, todo de couro, de cores severas, estofado em capitonê, com encosto e braços da mesma altura [cerca de $70 \mathrm{~cm}$ do chão]. É móvel sóbrio, muito usado em bibliotecas."

$40 \quad$ Associada com a arquitetura vitoriana, é um tipo de janela saliente que se projeta para fora do edifício. Protegida por vidros, aumentam a entrada de luz e criam a ilusão de um espaço maior.

41 "Pequeno armário envidraçado com estrutura leve e prateleiras destinado a guardar e expor objetos de adorno valiosos e/ou delicados." (MOUTINHO, 2011, p. 480).
} 
tungue ${ }^{42}$ lilás de tom médio, feitio de xales pendentes com bordado delicado na altura do peitoril da janela, executado ton sur ton em seda e salientados com fio de ouro velho. Ao invés de stores, colocar-se-iam cortinas de correr curtas feitas em filó ${ }^{33}$ branco-marfim até à altura do peitoril. Brise-brises ${ }^{44}$ nas janelas e nas portas de vidro, também em filó branco-marfim, com incrustações de filet ${ }^{45}$ artesanal.

No teto, um plafonier de cristal lapidado em prismas, ou um lustre de cristal de Veneza com pequenos abat-jours ${ }^{46}$ vieux-rose. Sobre o piano, uma luminária grande de porcelana de Copenhague com abat-jour lilás e malva, velado por um chiffon ${ }^{47}$ gris. Na mesa atrás do sofá, outra luminária grande do tipo castiçal, com pé esculpido em madeira escura e abat-jour de seda vieux-rose velado por um chiffon gris escuro e franjas de ouro velho. Numa das mesas, uma pequena luminária com pé de porcelana ou bronze artístico, com abat-jour lilás escuro, enquanto que na mesa que formaria o grupo juntamente à vitrine, outra luminária idêntica. Nas paredes do mesmo canto, dois appliques ${ }^{48}$ com pequenos abat-jours vieux-rose. Sobre o piano, um requintado tecido de bordado chinês ou um brocado em ouro. Almofadas de cetim ${ }^{49}$ gris e lilás, de lamé 50 de ouro velho e com enfeites de borlas e gregas de ouro velho. Em frente ao sofá, uma almofada grande e comprida de veludo lilás.

Sobre o piano, retratos em molduras de prata. Nas mesinhas, vasos de cristal lilás para violetas e rosas e pequenos objetos preciosos em prata. Na mesa atrás do sofá, uma jardineira de cristal com flores. Atrás do piano numa coluna apropriada, uma palmeira fina de grandes dimensões e, por toda a parte, plantas com folhas largas em

\footnotetext{
42 "Seda tecida à mão originariamente produzida na província de Shantung, na China. O xantungue é fino e macio, tecido com fios irregulares, para produzir uma superfície desigual. O xantungue do século XX é geralmente feito de seda misturada a algodão ou raiom, criando um tecido mais pesado que o original." (O'HARA, 1992, p. 292).

43 Esse tecido atende a diversas finalidades, das quais, cortinado. Sua transparência decorre dos fios espaçados e que permitem a circulação de ar, mas impedem a entrada de insetos. O tecido tem textura pesada e aceita ser pendurado. De textura macia, pode entrar em contato com a pele sem causa irritações.

$44 \quad$ "Pequena cortina de tecido fino ou de renda que guarnece as vidraças de janelas e portas." (MOUTINHO, 2011, p. 56).

45 "Espécie de bordado feito em rede de pequenas malhas amarradas manualmente [a maneira das redes de pesca] e fixada em bastidor; nos interstícios, são tecidos com agulha, motivos, figurativos ou não, que se destacam do fundo quadriculado com belo efeito decorativo." (MOUTINHO, 2011, p. 174).

46 "Acessório destinado a reduzir a intensidade da luz e/ou proteger a vista de um todo direto. [...] Pode pender do teto ou ser acoplado a um suporte de lâmpada. No caso da lâmpada de mesa - que é também um objeto de adorno - existe uma proporção a ser observada entre o abajur e o pé. [...] O abajur é um objeto marcadamente decorativo, e por isto a palavra passou a designar também o conjunto cúpula-suporte nas lâmpadas de mesa." (MOUTINHO, 2011, p. 1).

$47 \quad$ "Tecido extremamente leve e fino, produzido de fios muito torcidos. É feito de seda, lã ou fibras sintéticas." (O’HARA, 1992, p. 80).

48 "Luminária fixada à parede, mais ou menos a dois metros do chão, e que contribui para a iluminação de um ambiente; pode produzir luz difusa ou direta, às vezes voltada para o teto." (MOUTINHO, 2011, p. 14).

49 "Tecido de seda, macio e lustroso, que apresenta fios longos e brilhantes pelo direito, resultantes da maneira de tecer. [...] 0 cetim de algodão, feito deste material ou de fibra sintética, por ser encorpado e resistente e ter bom caimento, é próprio para cortinas, colchas, etc." (MOUTINHO, 2011, p. 88).

$50 \quad$ Tecido adornado por finas lâminas prateadas.
} 
cache-pots $^{51}$ de faiança italiana nas cores creme, lilás e gris. No vão da janela larga, uma jardineira de ferro acurado e feição antiga, com avenca e plantas semelhantes. Nas paredes, poucos quadros de grandes dimensões pintados à óleo, mas escolhidos criteriosamente. ${ }^{52}$

\section{Sala de jantar}

Ao se imaginar uma sala de jantar com 5,50m x 5,50m de área e um pé direito com de 3,50m de altura como continuação do living-room supramencionado, ou um hall acomodado entre os dois cômodos, com escadas para o andar superior e para os compartimentos no fundo da casa, era necessário que o mesmo nível de gosto e conforto fosse mantido (Ilustração 08). Se as portas envidraçadas do living-room fossem enfeitadas com brise-brises de filó branco marfim e seda lavável, e se havia comunicação direta entre as salas de visita e jantar, convinha escolher uma cor para os brise-brises capaz de se hamonizar com o conjunto. Neste caso, a cor de palha, ou de oca clara, ou de ouro velho seriam bem vindas, pois o esquema de cores na sala de jantar teria nuances de creme, palha e ouro velho como cores dominantes.
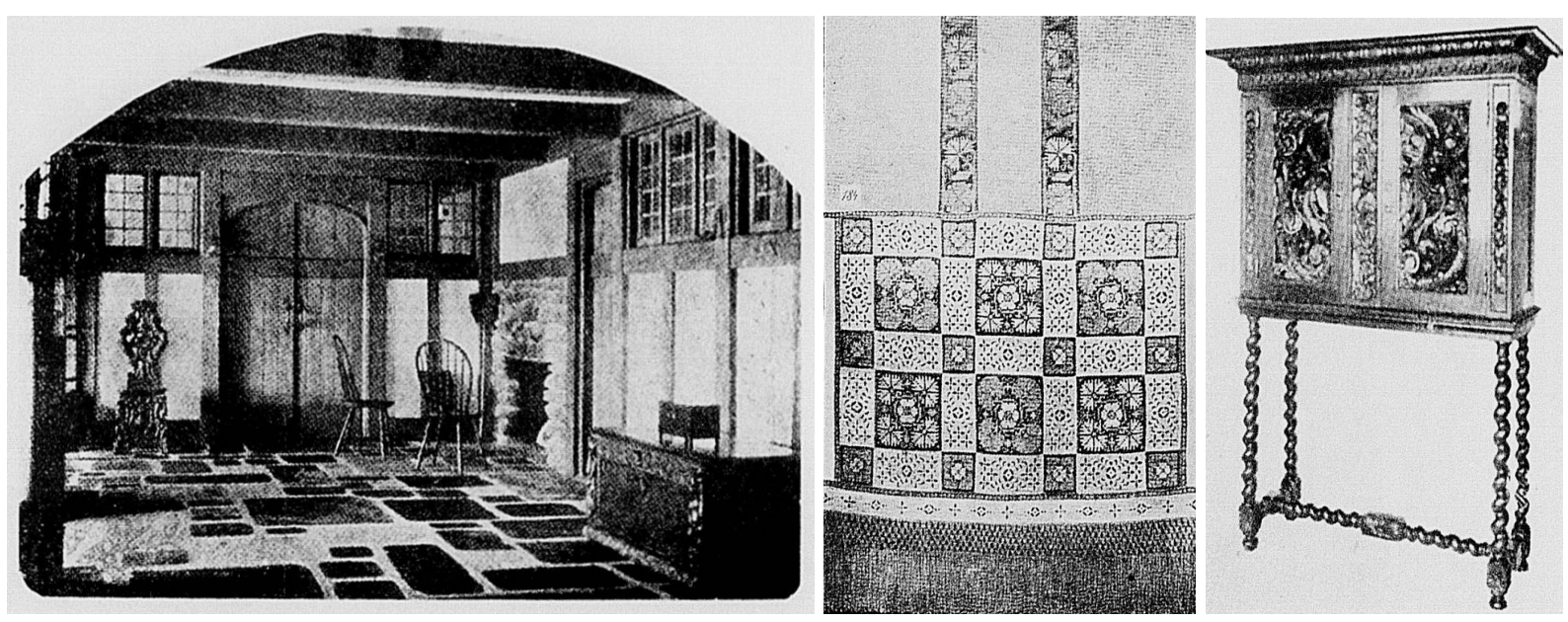

ILUSTRAÇÃO 08 - UM VESTÍBULO; UM STORE DE FILET E BORDADO INGLÊS APROPRIADO À SALA DE JANTAR; UM ARMÁRIO DE ESTILO ANTIGO USADO PARA MÚSICA OU GUARDAR DOCUMENTOS.

FONTE: VIDA DOMÉSTICA, RIO DE JANEIRO, JUL. 1927.

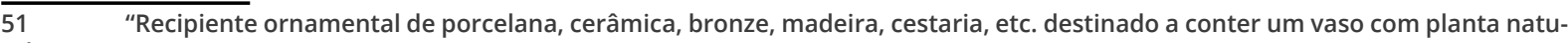
ral." (MOUTINHO, 2011, p. 349).

52 Essa descrição do living-room encontra-se em VIDA DOMÉSTICA, Rio de Janeiro, Edição 00111, jun.1927.
} 
Para os móveis escuros do tipo Renascença italiana, com escultura leve, o adequado era ter paredes pintadas a cola, foscas, em cor de palha um tanto carregada. $O$ teto feito com gesso sobre metal déployé53 branco marfim, poderia ter apenas uma moldura simples para marcar a passagem onde começa a parede. Obedecendo à altura do tampo do móvel principal, um buffet ${ }^{54}$ a ocupar o lugar de honra da parede maior, onde seriam organizados os lambris da mesma qualidade ou, pelo menos, na mesma tonalidade dos móveis. Lambris davam aspecto de conforto ao conjunto, pois parecia unir os diversos móveis com suas linhas sóbrias e singelas. Os painéis deviam, então, ter algo da mobília, porém muito discretamente. Não era necessário colocar lambris onde os móveis ficariam encostados à parede, pelo contrário, era mais elegante reservar um vão para embutir o buffet e os armários, desde que se tratasse de mobília completa no mesmo gênero e estilo, não de origem diversa.

A mobília de imbuia, ${ }^{55}$ cuja cor natural era apagada com um extrato de vieux-ché$n e^{56}$ e depois encerada, constava de uma mesa redonda com 1,40 m de diâmetro, de doze cadeiras singelas com alto espaldar sendo duas com braços, de um buffet com três portas e de um armário tríplice de cristal (cristaleira). Por cima do corpo do buffet, dois armários de canto com portas inteiriças de cristal e prateleiras também de cristal, e finalmente uma mesa retangular com três gavetas e prateleira em baixo para guardar bandejas e apetrechos do gênero. Para completar a mobília, uma mesa portátil de chá com tampo e ilhargas ${ }^{57}$ em cristal espesso, capacitada para se transformar em bandejas pendentes quando requeridas.

A mesa teria tampo inteiriço, portanto, não estensível, à medida que o pé seria esculpido com bastante largueza. Se fosse necessário aumentar o número de assentos em ocasiões festivas, apoiava-se um tampo postiço de diâmetro maior. As cadeiras seriam revestidas com couro gris, em cor relativamente fosca, com tachões de bronze e pátina ${ }^{58}$ florentina. Seguindo estilos antigos, os botões das gavetas na mesa retan-

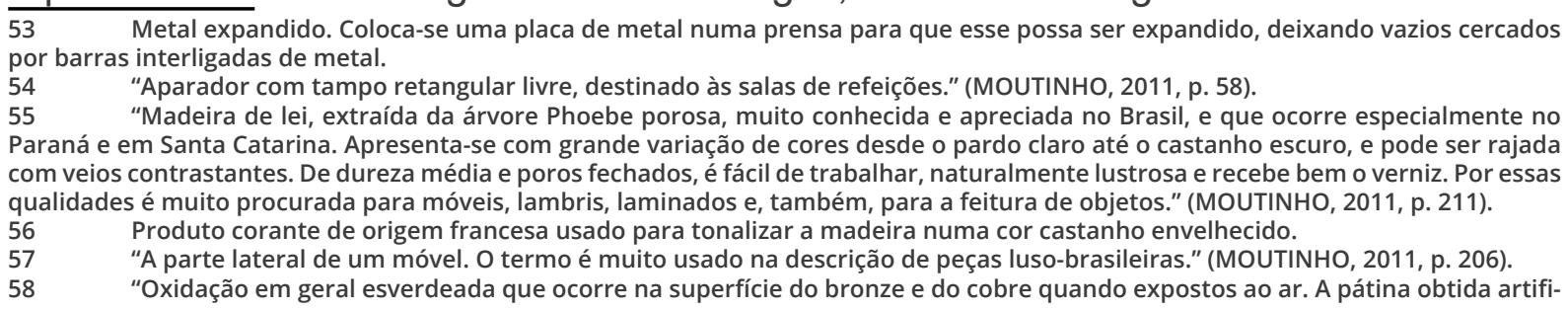


gular e as três portas do buffet levariam rosetas clássicas esculpidas, em contrapartida as diversas portas de cristal seriam guarnecidas com motivos naturalistas, igualmente esculpidos. Por fim, os lambris do entorno da sala teriam frisos esculpidos em forma de renda de vinte centímetros de altura, descansando sobre a moldura do lambril.

Acompanhando a mobília, colocavam-se no máximo quatro appliques nas paredes, um lustre esculpido em madeira com pequenas velas e abat-jours de seda na cor de ouro velho. Às vezes, as pessoas preferiam substituir o lustre de cerimônia por um abat-jour mais íntimo. Nesse caso, o diâmetro devia ser de setenta centímetros, com linhas singelas e coberto com seda cor de ouro velho, velada com chiffon gris ou bege escuro, e forrado com seda branca para centralizar o efeito da luz sobre a mesa. Existia ainda aqueles que desistiam da iluminação pendente, preferindo pequenas luminárias de prata, castiçais ou candelabros com velas. O que imperava era o gosto pessoal.

A cor dos respectivos abat-jours devia ser ouro velho. As cortinas podiam ser em veludo (chenille ${ }^{59}$ ) gris escuro com galões e grelots ${ }^{60}$ de prata envelhecida; ou da fazenda madras, ${ }^{61}$ uma espécie de voile ${ }^{62}$ preta com figuras aveludadas. Os stores e brise-brises que se adequavam bem às cortinas, deviam ser de filet mecânico, cor de barbante com rendas de linho clunye filets artesanais na mesma cor. Trazia sofisticação ao ambiente se as figuras e os arabescos dos filets fossem escolhidos de acordo com as esculturas em estilo antigo. Os stores deviam ser compridos e com franjas. As cortinas de madras exigiam um voile ou filó cru para a arrumação de stores, os quais deviam alcançar apena o peitoril da janela e ornados com rendas mais leves.

O tecido da mesa podia ser quadrado com diâmetro de 1,40m x 1,40m, em veludo com franjas de prata ou de brocado com fios de prata; ou de filet cru grosso, com incrustações de filets artesanais baseados nos motivos clássicos dos móveis. O tecido devia ter o mesmo diâmetro que a mesa, levando a sua volta franjas com pelo menos cinquenta centímetros de largura. O tapete de veludo, em nuances de gris, havana, azul cialmente por processos químico protege e embeleza tanto peças artísticas como outras de uso práticos." (MOUTINHO, 2011, p. 329). 59 "Fazenda com textura semelhante à de pele, criada ao tecerem-se em tufos os fios do urdume. Teve origem na França seiscentista. O chenille pode ser feito de algodão, seda, raiom ou lã." (O'HARA, 1992, p. 80).

60 "Galão de passamanaria do qual pendem borlas em geral redondas do mesmo material. É muito usado na terminação de cobertas, cortinas, xales." (MOUTINHO, 2011, p. 195).

61 "Tecido oriundo da cidade de Madras [índia] feito com fios de algodão e de seda formando quadrados de cores vivas. Era importado na Europa para a fabricação de lenços." (MOUTINHO, 2011, p. 268).

62 "Tecido leve, fino e transparente que pode ser de algodão, seda, náilon etc., e que, em decoração, presta-se para confecção de cortinas leves." (MOUTINHO, 2011, p. 480). 
escuro, branco, preto e verde resedá, ${ }^{63}$ sobretudo com padronagem espelhada ao invés de ter um centro pronunciado com cercaduras. Na mesa retangular, bandejas e objetos de prata para o uso diário, como fruteiras e cesta de pão, enquanto nas gavetas, toalhas e talheres. No buffet, as louças finas, e nos armários de cristal, peças raras de porcelana e prata, o que incluia, naturalmente, o serviço de cristal. Sobre o buffete por cima do armário tríplice de canto, outras peças escolhidas do mesmo gênero. No centro da mesa, um objeto de prata envelhecida, uma jardineira ou algo semelhante. Dentro da mesa de chá, o serviço de prata ou porcelana. Nas paredes, somente os appliques supracitados, exceto um grande e valioso prato de porcelana. Nos vãos das janelas, jardineiras baixas de ferro artístico, com plantas de folhas largas. Os lambris, cuja envergadura obedecia à altura do corpo do buffet, atingiria 1,12 m no topo exceto a parte esculpida, que acrescentaria outros vinte centímetros. A altura total do buffet e dos armários de canto seria de 1,72 m. ${ }^{64}$

\section{Cozinha}

As zonas destinadas aos serviços seguiam os mesmos preceitos artísticos das zonas sociais. No início da década, uma cozinha bem instalada em São Paulo devia ter as suas paredes forradas de azulejos para que o pó e a fumaça não grudassem em sua superfície, e que apenas uma lavagem diária pudesse mantê-los limpos. O chão devia ser de mosaico vermelho e branco, e o teto em "quadradinhos" para que a fumaça saísse. O forno de $1 \mathrm{~m}$ x 1,50 m era a peça mais importante do lugar, com estufas, grelha e secador de pratos, mas recomendava-se um forno a gás com graduação de calor. Os móveis deviam ser fortes: uma grande mesa de centro com tamboretes embaixo para não atrapalhar o serviço, um buffet de dois corpos para guardar as provisões, um armário para panelas, um aparador para partir os legumes e preparar os pratos, e algumas tábuas para suspender as caçarolas. ${ }^{65}$

Um pouco diferente da cozinha paulista, em meados dos anos 1920, na cozinha

\footnotetext{
63 Um tom de verde acinzentado. O nome deriva da cor das folhas Reseda Odorata.

64 Essa descrição da sala de jantar encontra-se em VIDA DOMÉSTICA, Rio de Janeiro, Edição 00112, jul.1927.

65

A VIDA MODERNA, São Paulo, Edição 00382, p. 28, 6.mai.1920.
} 
moderna do Rio de Janeiro tudo devia ser em branco, alvinitente, claro e ordenado. Os objetos seriam colocados em lugares preparados propositadamente para sua arrumação. Raramente os pavimentos eram cobertos por tijolos vermelhos; na prática, o piso era revestido com requintados mosaicos, ou aplicavam-se ladrilhos nas cores branco e preto, ou branco e azuis em disposições variadas, formando complicadas estrelas de linhas quebradas e até bizarros arabescos. Com cantos arredondados para evitar o acúmulo de poeira, às vezes, os ladrilhos subiam pelas paredes. Entretanto, se a cozinha mantivesse os tijolos vermelhos, cobriam-nos com um sólido linoleum claro.

Azulejos brancos, de barro polido ou de faiança revestiam as paredes de uma cozinha de luxo. Com o propósito de quebrar a monotonia, corriam embaixo, a mais ou menos vinte centímetros do solo, uma ou duas fileira de azulejos pardos. A mesma guarnição se repetia no alto, a vinte centímetros do teto. Quando não tinham esse revestimento, cobriam-se as paredes com ripolin branco. ${ }^{66}$ Nas opulentas residências, onde a criadagem era numerosa para conservar tudo limpo e intacto, a arte decorativa e o bom gosto ornamentavam as paredes brancas com artísticas decorações. As cozinhas deviam ser grandes e requintadas para receberem uma barra larga reproduzindo ramagens de tomates vermelhos, laranjas em amarelo luminoso combinados com verde vivo, etc. Além do uso de frutos nas pinturas dos frisos, cercaduras ou rodapés, raposas e coelhos eram igualmente temas recorrentes.

Os arquitetos projetavam cozinhas não úmidas que ocupavam pouco espaço, ou por outra, aproveitavam-se até do fundo das paredes do ambiente com a colocação de duas ou três ordens de prateleiras. Nas cozinhas brancas, os armários eram pintados com ripolin alvinitente. Geralmente, o menor dos armários ficava junto ao fogão, mantendo a mesma largura e profundidade. No seu interior, em diversas prateleiras, arrumavam-se as baterias de cozinha, ou seja, os utensílios necessários ao uso e em vários tamanhos. Em cozinhas pequenas e que se fazia mister ganhar lugar, colocavam-se sobre o armário, duas ou três travessas com escápulas para dependurar (llustração 09). Era costume que peças leves fossem penduradas nas prateleiras descobertas, desde que mantivessem aparência estética e hábil colocação.

Ripolin é uma marca de tinta esmalte apropriada para aplicações arquitetônicas, marítimas e outras. 


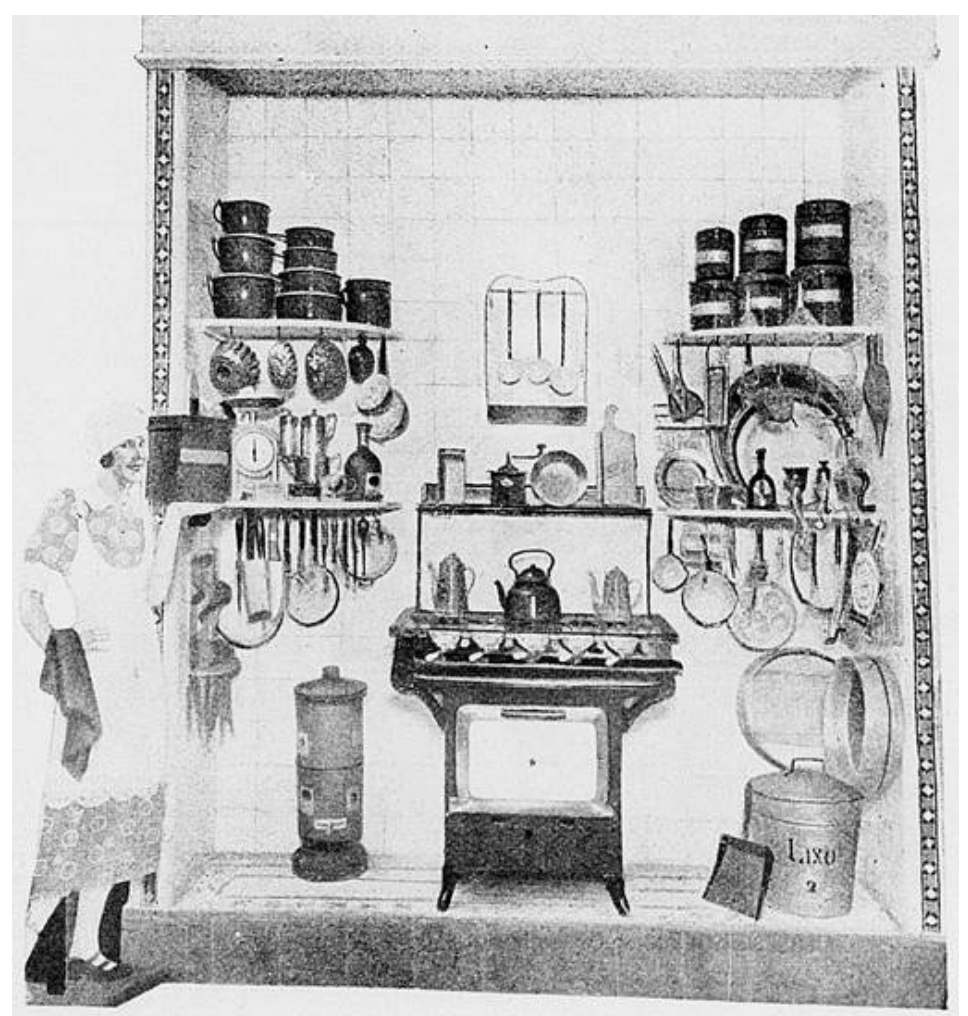

Ilustração 09 - Cozinha modelo da CASA Rajah, APRESEntando o fogão e todos os "trens" NECESSÁRIOS À COZINHEIRA.

FonTE: VIDA DOMÉSTICA, RIO DE JANEIRO, SET. 1924.

Isso é tanto verdade que as velhas caçarolas de cobres foram substituídas pelo alumínio e o níquel. As peças de alumínio constituíam o "trem da cozinha", vendido no período com um aparelhamento especial de madeira e com grampos de níquel onde as peças podiam ser dependuradas. Evitava-se assim de tocar as paredes, haja vista que 0 atrito constante acabaria por danificá-las. ${ }^{67}$

\section{A predominância do ecletismo}

As informações trazidas pelas revistas especializadas brasileiras espelham, de forma quase precisa, os fatos, as escolhas, os modos de vida da década de 1920, todavia, se os dados não estiverem sistematicamente organizados, a fragmentação dos eventos não permite uma visão holística do contexto. Esse fracionamento é consequência do período que se fez necessário para que o público desse uma resposta em relação 67 VIDA DOMÉSTICA, Rio de Janeiro, Edição 00081, out.1924. 
às novas ideias e a identificação do mesmo com as tendências em voga, mas também das constantes transformações que não cessavam de ocorrer, em todos os campos da vida humana.

Com o propósito de entender os anos que se seguiram e o perfil do goianiense que começava a ser moldado nos anos 1930, na qualidade de cidadão, foi imprescindível recuar no tempo e investigar o eixo Rio-São Paulo. Naqueles dias, a revistas especializadas pensavam numa sociedade "endinheirada" e frívola para justificar as novas tipologias de ambientes que surgiam aceleradamente (das quais, muitas já desapareceram). Vale registrar que falar do conflito mundial ocorrido entre 1914 e 1918 era um assunto quase proibido nesses periódicos. Quatro anos de guerra furiosa estremeceram a Europa e suas funestas consequências continuaram a ser sentidas em todo o planeta. Organizaram-se congressos de paz com o intuito das nações se unirem para pacificar o mundo. Contudo, a guerra avançava medonha e devastadora entre os povos, e a expectativa era que continuasse enquanto ódios, ambições e vaidades persistissem na face terrestre. ${ }^{68}$ Em suma, preponderava um sentimento de desesperança e negação pelas coisas nacionais; aliás, as influências exteriores eram tão naturais e presentes na vida dos brasileiros que até os apetrechos domésticos simples mantinham as nomenclaturas em inglês ou, preferencialmente, em francês (bob-window, bay-window, living-room, fumoir, buffet, etagère, fauteuil, chaise-longue, abat-jour, applique, plafonier, chiffon, vieux-rose, dentre outros termos).

Os projetos arquitetônicos anteriores ao século XX seguiam diretrizes que davam predominância aos eixos de simetria. Todavia, com as concepções do pós-guerra subverteram aquilo que a liturgia acadêmica consagrara. Essa mudança ocorreu na habitação e, obviamente, no mobiliário, na paramentação e na tapeçaria. Em 1925, estabeleceram-se as bases de um novo sentimento técnico artístico, cujo espírito, sofrendo a evolução do seu ciclo, se modificou completamente. Os intelectuais da época tinham consciência de que aquilo que se fazia na Europa em 1925 em relação ao que se fazia no Brasil nos dez anos seguintes, era "velharia". Isso significa que muita gente temia que o modernimo, o cubismo ou o chamado estilo "caixa d'água" caíssem de moda e, 
por isso, preferiam o ecletismo dos estilos. ${ }^{69}$

Enfim, nos arranjos da casa, estilos do passado não eram repudiados pelo modernismo, desde que a Arte fosse considerada, adequando-os às exigências racionais e práticas da vida presente daquele tempo, ou seja, sem decorações supérfluas. Dizendo em outras palavras, o móvel moderno ou de inspiração antiga, além do seu lado racional, deveria ter os elementos estilísticos individuais que formavam a sua fisionomia, complementando a casa - os quais eram, geralmente, inseridos pela mulher.

Nas palavras de Gio Ponti, "a Arte de um arredamento não deve ser representada pelo empréstimo formal de algumas reminiscências estilísticas, mas da presença ativa de uma cultura universal." 70

\section{Referências}

MOUTINHO, Stella et. al. Dicionário de artes decorativas \& decoração de interiores. Rio de Janeiro: Lexikon, 2011.

O'HARA, Georgina. Enciclopédia da moda. São Paulo: Companhia das Letras, 1992.

Revista ACRÓPOLE, São Paulo, ano 1, n. 9, jan.1939. Disponível em: disponível em $<$ http://www.acropole.fau.usp.br/>. Acesso em: xxxx

VIDA DOMÉSTICA, Rio de Janeiro, Edição 00068-00069, dez.1923. Disponível em: <http://bndigital.bn.gov.br/acervo-digital/vida-domestica/830305>. Acesso em: mai. e jun. 2020.

VIDA DOMÉSTICA, Rio de Janeiro, Edição 00075, abr.1924. Disponível em: <http:// bndigital.bn.gov.br/acervo-digital/vida-domestica/830305>. Acesso em: mai. e jun. 2020.

VIDA DOMÉSTICA, Rio de Janeiro, Edição 00077, jun.1924. Disponível em: <http:// bndigital.bn.gov.br/acervo-digital/vida-domestica/830305>. Acesso em: mai. e jun. 2020.

VIDA DOMÉSTICA, Rio de Janeiro, Edição 00077, jun.1924. Disponível em: <http:// bndigital.bn.gov.br/acervo-digital/vida-domestica/830305>. Acesso em: mai. e jun. 2020.

VIDA DOMÉSTICA, Rio de Janeiro, Edição 00079, ago.1924. Disponível em: <http:// bndigital.bn.gov.br/acervo-digital/vida-domestica/830305>. Acesso em: mai. e jun. 
2020.

VIDA DOMÉSTICA, Rio de Janeiro, Edição 00081, out.1924. Disponível em: <http:// bndigital.bn.gov.br/acervo-digital/vida-domestica/830305>. Acesso em:mai. e jun. 2020.

VIDA DOMÉSTICA, Rio de Janeiro, Edição 00094, nov.1925. Disponível em: <http:// bndigital.bn.gov.br/acervo-digital/vida-domestica/830305>. Acesso em: mai. e jun. 2020.

VIDA DOMÉSTICA, Rio de Janeiro, Edição 00095, dez.1925. Disponível em: <http:// bndigital.bn.gov.br/acervo-digital/vida-domestica/830305>. Acesso em: mai. e jun. 2020.

VIDA DOMÉSTICA, Rio de Janeiro, Edição 00101, jul.1926. Disponível em: <http:// bndigital.bn.gov.br/acervo-digital/vida-domestica/830305>. Acesso em:mai. e jun. 2020.

VIDA DOMÉSTICA, Rio de Janeiro, Edição 00106, dez.1926. Disponível em: <http:// bndigital.bn.gov.br/acervo-digital/vida-domestica/830305>. Acesso em: mai. e jun. 2020.

VIDA DOMÉSTICA, Rio de Janeiro, Edição 00111, jun.1927. Disponível em: <http:// bndigital.bn.gov.br/acervo-digital/vida-domestica/830305>. Acesso em:mai. e jun. 2020.

VIDA DOMÉSTICA, Rio de Janeiro, Edição 00112, jul.1927. Disponível em: <http:// bndigital.bn.gov.br/acervo-digital/vida-domestica/830305>. Acesso em: mai. e jun. 2020.

VIDA DOMÉSTICA, Rio de Janeiro, Edição 00117, dez.1927. Disponível em: <http:// bndigital.bn.gov.br/acervo-digital/vida-domestica/830305>. Acesso em: mai. e jun. 2020.

VIDA DOMÉSTICA, Rio de Janeiro, Edição 00124, jul.1928. Disponível em: <http:// bndigital.bn.gov.br/acervo-digital/vida-domestica/830305>. Acesso em: mai. e jun. 2020.

VIDA DOMÉSTICA, Rio de Janeiro, Edição 00133, abr.1929. Disponível em: <http:// bndigital.bn.gov.br/acervo-digital/vida-domestica/830305>. Acesso em: mai. e jun. 2020.

VIDA DOMÉSTICA, Rio de Janeiro, Edição 00138, set.1929. Disponível em: <http:// bndigital.bn.gov.br/acervo-digital/vida-domestica/830305>. Acesso em: mai. e jun. 2020.

REVISTA FEMININA, São Paulo, Edição 089, ano VIII, out.1921. Disponível em: https://bibdig.biblioteca.unesp.br/handle/10/36. Acesso em: mai. e jun. 2020.

REVISTA FEMININA, São Paulo, Edição 139, ano XII, dez.1925. Disponível em: https://bibdig.biblioteca.unesp.br/handle/10/36. Acesso em: mai. e jun. 2020.

A VIDA MODERNA, São Paulo, Edição 00379, 25.mar.1920. Disponível em: http:// memoria.bn.br/DocReader/docreader.aspx?bib=189740\&pesq=. Acesso em: mai. 
e jun. 2020.

A VIDA MODERNA, São Paulo, Edição 00382, 6.mai.1920. Disponível em: <http://memoria.bn.br/DocReader/docreader.aspx?bib=189740\&pesq=>. Acesso em:mai. e jun. 2020.

A VIDA MODERNA, São Paulo, Edição 00375, 29.jan.1925. Disponível em: <http:// memoria.bn.br/DocReader/docreader.aspx?bib=189740\&pesq=>. Acesso em: mai. e jun. 2020.

A VIDA MODERNA, São Paulo, Edição 00494, 3.abr.1925. Disponível em: <http://memoria.bn.br/DocReader/docreader.aspx?bib=189740\&pesq=>. Acesso em: mai. e jun. 2020.

Revista A Casa, Rio de Janeiro, Edição 0026, jun. 1926. Disponível em: <http://memoria.bn.br/DocReader/docreader.aspx?bib=690422\&pesq=>. Acesso em mai. e jun. 2020.

Revista A Casa, Rio de Janeiro, Edição 0033, jan. 1927. Disponível em: <http://memoria.bn.br/DocReader/docreader.aspx?bib=690422\&pesq=>. Acesso em: mai. e jun. 2020.

Revista A Casa, Rio de Janeiro, Edição 0063, jul. 1929. Disponível em: <http://memoria.bn.br/DocReader/docreader.aspx?bib=690422\&pesq=>. Acesso em: mai. e jun. 2020.

Revista A Casa, Rio de Janeiro, Edição 0147, ago. 1936. Disponível em: <http://memoria.bn.br/DocReader/docreader.aspx?bib=690422\&pesq=>. Acesso em: mai. e jun. 2020.

SANTOS, José de Almeida. Mobiliário Artístico Brasileiro. Vol. 1 - Tomos 1, 2 e 3. São Paulo: Coleção Museu Paulista, 1963.

RECEBIDO EM: 08/06/2020

APROVADO EM: $24 / 06 / 2020$

PUBLICADO EM: 23/07/2020 